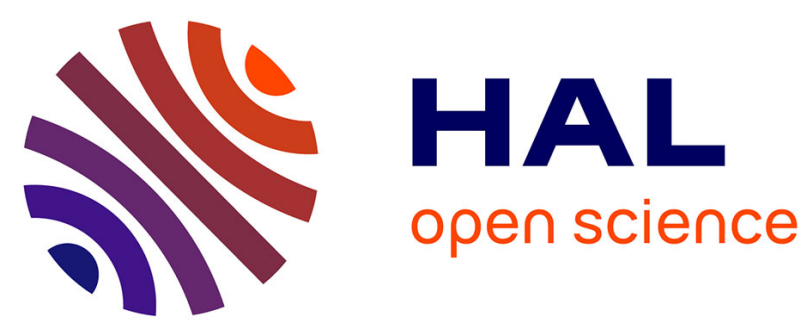

\title{
Past distribution of the Burrowing Owl (Athene cunicularia) in the Lesser Antilles: New evidence from Saint Martin and Guadeloupe (F.W.I.) Monica Gala, Véronique Laroulandie, Arnaud Lenoble
}

\section{- To cite this version:}

Monica Gala, Véronique Laroulandie, Arnaud Lenoble. Past distribution of the Burrowing Owl (Athene cunicularia) in the Lesser Antilles: New evidence from Saint Martin and Guadeloupe (F.W.I.). Wilson journal of ornithology, 2020, 132 (4), pp.868-880. 10.1676/19-00135 . halshs-03355343

\section{HAL Id: halshs-03355343 \\ https://shs.hal.science/halshs-03355343}

Submitted on 27 Sep 2021

HAL is a multi-disciplinary open access archive for the deposit and dissemination of scientific research documents, whether they are published or not. The documents may come from teaching and research institutions in France or abroad, or from public or private research centers.
L'archive ouverte pluridisciplinaire HAL, est destinée au dépôt et à la diffusion de documents scientifiques de niveau recherche, publiés ou non, émanant des établissements d'enseignement et de recherche français ou étrangers, des laboratoires publics ou privés. 


\title{
Past distribution of the Burrowing Owl (Athene cunicularia) in the Lesser Antilles: New evidence from Saint Martin and Guadeloupe (F.W.I.)
}

\author{
Monica Gala, ${ }^{1 *}$ Véronique Laroulandie, ${ }^{1}$ and Arnaud Lenoble ${ }^{1}$ \\ PACEA - UMR CNRS 5199, Université de Bordeaux, Pessac Cedex, France
}

*Corresponding author: monica.gala@u-bordeaux.fr

\begin{abstract}
Recent excavations from late Pleistocene to Historical period sites on the islands of Guadeloupe and Saint Martin yielded bones of the Burrowing Owl (Athene cunicularia). The osteological description of the remains combined with the location of fossil-bearing sites and historical accounts show this owl to have been present across the Guadeloupe islands in historical periods. This species has been identified in multiple archaeological sites, including those reported here, attesting to the near continuous distribution of this owl throughout the pre-Columbian period in the north of Lesser Antilles. Taken together, these results challenge the previous hypothesis of a relict distribution of the Burrowing Owl as a consequence of climatically induced modifications of the Caribbean environment since the last glaciation. Received 19 November 2019. Accepted 22 February 2021.
\end{abstract}

Key words: biogeography, extinction, Holocene, late Pleistocene, Strigidae, West Indies.

\section{Distribution passée de la Chouette des terriers (Athene cunicularia) dans les Petites Antilles : nouvelles données de Saint Martin et de la Guadeloupe (Antilles françaises)}

RÉSUMÉ (French)-Les fouilles réalisées ces dernières années sur des sites du Pléistocène supérieur à l'époque historique, sur les îles de la Guadeloupe et de Saint-Martin, ont livré des ossements de Chouette des terriers (Athene cunicularia). La description ostéologique des vestiges fossiles conjuguée à la localisation des cavités et aux récits historiques, montre que cette chouette était présente dans les îles de la Guadeloupe à l'époque historique. La présence de cette espèce dans des sites archéologiques, dont les nouvelles mentions apportées par ce travail, témoigne d'une distribution quasi continue de ce taxon dans la partie nord des Petites Antilles à l'époque précolombienne. Ces résultats remettent en question l'hypothèse précédente d'une distribution relictuelle de cette espèce en conséquence des modifications climatiques du milieu caribéen au sortir de la dernière glaciation.

Mot clés : Antilles, biogéographie, extinction, Holocène, Pléistocène supérieur, Strigidés. 
The Neotropical region is well known for its rich and diverse avian fauna (Jenkins et al. 2013), particularly nocturnal birds of prey. With 80 recognized species, this region is home to a third of the world's Strigiformes (Rangel-Salazar and Enríquez 2017). Caribbean bird communities are, by comparison, relatively sparse. For example, the Greater Antilles sustains only 9 species of Strigiformes (Raffaele et al. 2003), only one of which occurs in the Lesser Antilles: the Lesser Antillean Barn Owl (Tyto insularis), present on St. Vincent, Granada, and Dominica (König and Weick 2008).

The fossil record of the Caribbean depicts a much greater variety of Strigiformes (Hume and Walters 2012), with Pleistocene fossil remains from the region, including the Bahamas, comprising 4 extinct species of Tytonidae and an equal number of Strigidae (Wetmore 1937, Brodkorb 1969, Arredondo 1976, 1982; Arredondo and Olson 1994, Suárez and Olson 2015). Tyto noeli is the only one of these species documented in the Lesser Antilles, as a late Pleistocene fossil from Barbuda (Steadman and Hilgartner 1999).

Another strigid also inhabited the Lesser Antillean Islands up to historical times, the Burrowing Owl (Athene cunicularia Molina 1782). This small owl has a wide pan-American distribution (Marks et al. 1999) with its still unclear taxonomy comprising some 15-18 subspecies (König and Weick 2008, Gill and Donsker 2019). Three or four extant subspecies currently occur in the Caribbean. One subspecies is known from different parts of Cuba and Hispaniola, A. c. troglodytes (Wetmore and Swales 1931), while another inhabits Florida and several islands of the northern Bahamas, A. c. floridana (Ridgway 1874), to which the population of Inagua Island, located in the south of the same archipelago and originally named A. c. bahamahensis (Cory 1891), was synonymized. South of the Caribbean Basin, $A$. c. brachyptera (Richmond 1896) inhabits Margarita Island, and A. c. arubensis (Cory 1915) currently occupies Aruba, synonymous with the latter taxon according to several researchers (Weick 2006, Poulin et al. 2011, Gill and Donsker 2019), and reconsidered as a subspecies by Weick (2018).

In addition, 2 now-extinct forms of $A$. cunicularia were present in the Lesser Antilles during historical times. A small form specific to the islands of Nevis and Antigua, A. c. amaura (Lawrence 1878), is distinguished from a larger, melanic form known only from the island of Marie-Galante, A. c. guadeloupensis (Ridgway 1874). With the exception of a 1956 observation made on the islet of Redonda (Bond 1971), no Burrowing Owls have been seen in the Lesser Antilles since the end of the 19th century. Native raptor populations in the Caribbean have declined significantly as a consequence of the extensive alteration of West Indian ecosystems since European colonization, which resulted in significant habitat reductions following massive deforestation, the introduction of both predators and competitors, as well as hunting (Wiley 1986). Large raptors, in particular, consumed mainly endemic terrestrial mammals (Arredondo 1976, Olson 1978), with the disappearance of the latter driving these species to extinction (Steadman and Hilgartner 1999, Suárez and Olson 2015). Other smaller raptors also disappeared, suggesting additional factors to underlie the extirpation of Lesser Antillean avifauna. This is particularly the case of the Burrowing Owl, which was previously more widely distributed in the Caribbean, as evidenced by fossils collected from paleontological deposits throughout the West Indies (Olson and Steadman 1977, Olson and Hilgartner 1982, Morgan 1994, Pregill et al. 1994).

According to the hypothesis advanced by Pregill and Olson (1981), the disappearance of this owl would be mainly related to climatically induced changes that emerged at the end of the last glacial cycle. Burrowing Owl populations would have been negatively affected by a reduction in their (xeric) habitats coincident with late Pleistocene climate change, producing a relict distribution following the development of moist tropical forests during the post-Glacial period (i.e., the Holocene). This would be reflected in the lower number of islands with owl populations as well as in the lower frequency of owl bones recovered from Holocene fauna assemblages.

Demonstrating this hypothesis is difficult, however, as it requires a reliable chronological framework that remains difficult to establish for the Caribbean based on available data (Morgan 1994, Cooke et al. 2017). This issue is further confounded by the current lack of detailed analyses of the archaeological and paleontological record in the Lesser Antilles (Olson 1978, Pregill et al. 1994). As a consequence, the alternative hypothesis, that the extinction of Lesser Antillean forms was mainly driven by direct or indirect human-induced changes in the last millennium, cannot be rejected. 
In this work, we explore whether the distribution of the Burrowing Owl was climatically induced or reflects changing ecological conditions. By combining historical and museum sources with an analysis of paleontological and archaeological specimens recovered during excavations over the last decade we shed new light on the Burrowing Owl in the Lesser Antilles. Our work focuses primarily on the islands of Guadeloupe, located in the middle of the Lesser Antilles, where the Burrowing Owls occurred uniquely on Marie-Galante until the late 19th or early 20th century (Noble 1916, Danforth 1939, Bond 1945). Here we use the term "islands of Guadeloupe" to refer to 2 contiguous islands of Basse Terre and Grande Terre, as well as Les Saintes, La Désirade, and Marie-Galante. We analyzed strigid remains from 7 late Pleistocene to Historical period sites from the archipelago, as well as a fossil specimen from a pre-Columbian site on Saint Martin in the northern Lesser Antilles. When compared to our current understanding of the regional distribution of this taxon, our large dataset allows us to challenge Pregill and Olson's hypothesis that the relict distribution observed since the end of the $19^{\text {th }}$ century reflects a climatically induced contraction of this bird's habitat.

\section{Methods}

Museum specimens and historical sources Previous accounts of the Burrowing Owl in Guadeloupe were collated from historical accounts of the islands' colonial settlement, as well as historical texts and previous ornithological research concerning the local wildlife. Online museum inventories were also consulted to identify the origin of museum specimens attributed to the Guadeloupean subspecies of the Burrowing Owl.

\section{Archaeological and paleontological evidence}

The peopling of the Lesser Antilles began with the Archaic Age, also known as the Preceramic period, during the mid-Holocene, some 6,000 years ago (Keegan et al. 2013, Fitzpatrick 2015). This period ends around $80 \mathrm{BCE}$ with the onset of the Ceramic Age, which continues on the Guadeloupe Islands until approximately 1600 CE (Hofman et al. 1999). This latter period is subdivided into 3 phases: the Early Ceramic Age, up to $800 \mathrm{CE}$; the Late Ceramic Age, up to 1492; and the Contact period, which witnessed Carib populations having both peaceful and hostile exchanges with newly arriving European colonists who became permanently established in the early 17th century (Keegan and Hofman 2017). In addition to material from these different periods, we included specimens from the late Pleistocene (from 40,000 to approximately $12,500 \mathrm{ybp}$ ) and early Holocene (12,500-6,000 ybp). Analyzed fossil and subfossil material comes from 8 archaeological and paleontological sites on 4 islands in the Lesser Antilles: 5 sites from Marie-Galante (Grotte Blanchard, Grotte Blanchard 2, Grotte Cadet 2, Abri Cadet 3, Folle Anse) dating from the late Pleistocene to present; and the others dating from the Ceramic period or beginning of the Historical period in Grande Terre (Grotte des Bambous), La Désirade (Pointe Gros Rempart 6), and Saint Martin (Hope Estate) (Fig. 1, Supplemental Material S1).

\section{Taxonomic identification and osteological description}

Strigiformes bone remains from the islands of Guadeloupe and Saint Martin were compared with Tyto, Megascops, Margarobyas, Otus, Athene, Strix, and Asio from the osteological collections housed at the PACEA laboratory of the University of Bordeaux (PACEA), the Musée archéologique Edgar Clerc - Le Moule (MEC), the Muséum national d'histoire naturelle in Paris (MNHN), and the Paleobiology and Birds Collections of the National Museum of Natural History, Smithsonian Institution in Washington DC (USNM). Details concerning the comparative material is provided in the Supplemental Material (S2, S3). 
Skeletal characters described by Kessler (2017) for the genus Athene and by Olson and Hilgartner (1982) for Megascops nudipes and Athene cunicularia were used to identify remains to species. In the case of difficult to identify or fragile remains, 3D surface meshes of specimens were produced using microtomography with a ICTscanner (GE Phoenix vjtomejx s) at the PLACAMAT Platform of the University of Bordeaux in order to facilitate comparisons with osteological collections. Remains that did not display all diagnostic skeletal characters were tentatively assigned to Burrowing Owl (cf. Athene cunicularia).

Anatomical nomenclature essentially follows Baumel and Witmer (1993), although modified in some instances. Measurements were recorded according to von den Driesch's (1976) protocol. Measurements of greatest length (GL), breadth of the proximal end (Bp), and breadth of the distal end (Bd) were taken with digital calipers to the

nearest $0.1 \mathrm{~mm}$. For long bones, we compared measurements of fossil specimens to published data concerning both modern and ancient material (Cory 1886, Ridgway 1914, Olson and Hilgartner 1982), supplemented by our measurements of modern A. c. troglodytes specimens from Haiti and fossil specimens from Burma Quarry in Antigua (Supplemental Table S1).

The number of identified specimens (NISP), minimum number of elements (MNE), and minimum number of individuals ( $\mathrm{MNI}$ ) were established for each stratigraphic unit, with age determined by the maturity of the bones (juvenile-subadult versus adult) and female specimens when medullary bone was present.

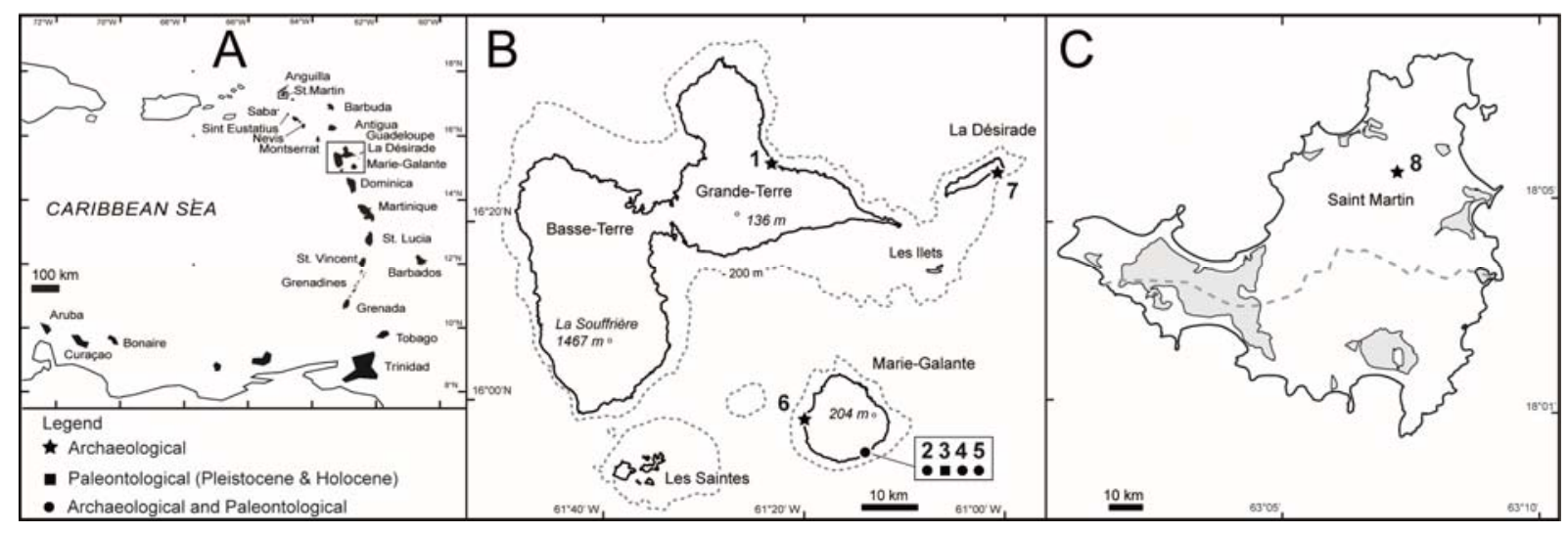

Figure 1. Maps of the Lesser Antilles (A), Guadeloupe (B), and Saint Martin (C) islands with the locations of both archaeological and paleontological sites. 1-Grotte des Bambous, 2-Grotte Blanchard, 3-Grotte Blanchard 2, 4-Grotte Cadet 2, 5-Abri Cadet 3, 6-Folle Anse, 7-Pointe Gros Rempart 6, 8-Hope Estate.

\section{Results}

\section{Museum specimens}

The holotype of the Guadeloupean form Athene cunicularia guadeloupensis (Ridgway 1874) is a specimen from the Lasfrenaye collection acquired in 1865 by the Boston Society of Natural History (Barrow 2000). This specimen now forms part of the Museum of Comparative Zoology collection at Harvard University (MCZ), inventoried under number 74167. The MCZ catalogue mentions L'Herminier as the collector. L'Herminier gave Lasfrenaye several birds from Guadeloupe, some of which were used to describe species in the 1840s (Lasfrenaye 1843, 1844). Based on the descriptions provided by Lasfrenaye, it appears that the MCZ specimen was collected in Guadeloupe during the 1840s or shortly before. This interpretation is supported by the mention of a small Strigidae on the list of birds of 
Guadeloupe compiled by L'Herminier between 1828 and 1843 (Lawrence 1878a), appearing under the name "Strix nudipes, Daudin." At the beginning of the 19th century, the Puerto Rican Screech Owl Megascops nudipes, also present on the Virgin Islands, referred to as Strix nudipes in Daudin's 1800 description, had been named, while the Lesser Antillean form of Burrowing Owl remained undescribed. This explains why L'Herminier referred to the Guadeloupe Burrowing Owl as the Puerto Rican Screech Owl.

The MCZ register indicates "Guadeloupe" as the holotype locality. During the $19^{\text {th }}$ century, collectors often provided little precise information about where the birds were collected, it thus remains possible that the specimen was collected from an island administratively dependent on Guadeloupe (e.g., Marie-Galante).

Seven other specimens were subsequently collected from the islands of Guadeloupe (Noble 1916, Danforth 1939, Deignan 1961), 6 from Marie-Galante and 1 mentioned simply as coming from the Guadeloupe islands without any further precision (Supplemental Material S4).

Noble (1916) states that, when he visited Guadeloupe in 1914, the owl was already extirpated from Marie-Galante, with only 5 stuffed specimens preserved at the Musée L'Herminier. Concerning these specimens, he mentions that "The conservateur, however, assured me that they came from Marie Galante many years ago" (Noble 1916: p. 377). The report of 5 specimens is consistent with the number of specimens given by the Museum to the MCZ and those seen by Danforth during his visit to Guadeloupe in 1937 (Danforth 1939). This would corroborate Noble's account that no other specimens were acquired by the Musée L'Herminier after 1914.

In addition, Ober, who carried out a major bird collection in Guadeloupe in 1877, did not find the species. Ober also visited the Musée L'Herminier in Pointe-à-Pitre, and Lawrence, reporting the words of the naturalist, wrote: "Mr. Ober (who arrived here on November 13) informs me that he could learn of no species of owl inhabiting Guadeloupe, nor does the museum there possess a specimen" (Lawrence 1878b: p. 236).

The Musée L'Herminier specimens being collected from Marie-Galante, the fact that neither Ober nor Noble recorded the owl in Guadeloupe, and imprecisions concerning the type locality, led Bond (1936) and Danforth (1939) to conclude that the species never inhabited Guadeloupe. In addition, the absence of an owl from the Musée L'Herminier during Ober's visit, combined with Noble's testimony (1916) that the bird was no longer present on Marie-Galante during his visit, places the collection of the last examples of the Burrowing Owl on Marie-Galante between the end of the 1870s and the 1910s. This period also witnessed the introduction of the mongoose (in 1884 on Guadeloupe and around 1900 on Marie-Galante; Horst et al. 2001). This concordance prompted Noble (1916) to propose that the disappearance of the owl was linked to the introduction of the mongoose, an interpretation reiterated by Bond (1936) and Danforth (1939) as well as more recent scholars (e.g., Greenway 1967, Hume 2017).

In the end, the museum specimens reinforce the presence of the Burrowing Owl on Marie-Galante until at least the end of the 19th century. In addition, the collections include only a small number of Guadeloupean forms. The same is true of the other Lesser Antilles variety, A. c. amaura; Ober was only able to secure (i.e., contra payment) 3 specimens during his stay in Antigua in 1878 (Lawrence 1878b). This observation led several authors to consider that the Burrowing Owl was already scarce at that time (e.g., Greenway 1967).

\section{Historical sources}

Historical $17^{\text {th }}$ century textual sources suggest that the Burrowing Owl was more widespread than it was in the 19th century. Father Breton's French-Caribbean dictionary (1665) indicates that the Amerindian word mouroucouli refers to an owl. While this suggests the presence of nocturnal raptors, it says nothing about their location or the taxon(s) concerned. Father Breton mentions the presence of a strigid on Guadeloupe in the $17^{\text {th }}$ century: "The owl is not as large as the one in France, it is blacker, and its song is not quite as sad" (Breton 1978: p. 36). This brief description is insufficient to identify 
the bird described by Breton, especially since the 2 species of nocturnal raptors, Tyto insularis and Athene cunicularia, both melanic forms, are known to have been present in the Lesser Antilles during the historical period. The mention of a song helps to rule out the Barn Owl, which suggests that Breton was actually referring to the Burrowing Owl, unless another form of Strigidae was present during the $17^{\text {th }}$ century in Guadeloupe.

A more detailed account is provided by Du Tertre, who described wildlife on the Lesser Antilles during the first decades of European colonization (Du Tertre 1667): "At night on almost all our islands, we hear a kind of Chaüant, who throws a gloomy cry, as if to cry au Canot: from where it got it name, it often sent inhabitants near the sea, on the shoreline, running in the belief that they were poor inhabitants, whose canots were in danger of being smashed against the rocks, and who were calling for help; they are no bigger than doves, but they are all similar in their plumage to owls, which we commonly see in France, they have 2 or 3 small feathers on both sides of the head, which seem to be ears. It reminds me of having sat with a dying Guadeloupean, I saw 7 or 8 of these canots on and under his bed, they made a desperate noise, so that all in the house wanted to persuade me that they were devils; all night long they did nothing but come and go, screaming continuously, but as day came, they left the house" (Du Tertre 1667, t. 2: p. 278, our translation).

Du Tertre's description contains several elements (smaller strigiform than Athene noctua, "which we commonly see in France," gloomy song, gregarious behavior) that suggest the Burrowing Owl. The regularity and ease with which the bird is heard also suggest that the owl was common during this period. This account also suggests the Burrowing Owl had a wide geographical distribution that included Guadeloupe, where the scene reported by Du Tertre takes place. If by "almost all our islands," Du Tertre meant all the French possessions in the Caribbean (e.g., Martinique, Guadeloupe, MarieGalante, St Kitts, St Barthélemy), then it would appear that the Burrowing Owl was present on a larger number of islands. One uncertainty remains in this description, that of the subspecies present in Guadeloupe (i.e., the large form from Marie-Galante, the small form known from St Kitts and Nevis, or a third one).

In the end, accounts from early visitors to the region paint the image of a bird whose distribution was wider than what can be deduced from $19^{\text {th }}$ century collections. In other words, these accounts suggest the range of this species to have contracted over the first 3 centuries of the Colonial period, at least for the islands of Guadeloupe.

\section{Archaeological and paleontological evidence}

We identified about a hundred owl remains (NISP 1/4 102) that represent at least 22 individuals (Table 1). The high proportion of complete and almost complete bones (49\%) allowed numerous remains to be attributed to a species level. In total, 72 bones from 6 sites were identified as belonging to the Burrowing Owl. Moreover, 30 remains bear multiple traits typical of Athene cunicularia, but were tentatively assigned to the Burrowing Owl (cf. A. cunicularia) because of their fragmentation or morphometric character that differ in some respects from specimens in the modern comparison sample (Table 2, Supplemental Material S5 and Fig. S1-S3). The remains cautiously referred to Athene cunicularia from Folle Anse and PGR 6 are the only strigid remains from these sites and are described in detail in the Supplemental Material (S5). 
Table 1. Number of identified specimens (NISP) and minimal number of individuals (MNI) of Strigiformes from the 8 sites. a The abbreviation "cf. " (conformis) is used for remains tentatively referred to the Athene cunicularia.

\begin{tabular}{llllll}
\hline \multicolumn{1}{c}{ Island } & \multicolumn{1}{c}{ Site } & $\begin{array}{c}\text { Athene } \\
\text { cunicularia }\end{array}$ & $\begin{array}{c}\text { cf. } A . \\
\text { cunicularia }^{a}\end{array}$ & $\begin{array}{c}\text { Total } \\
\text { NISP }\end{array}$ & $\begin{array}{c}\text { Total } \\
\text { MNI }\end{array}$ \\
\hline Grande Terre & Grotte des Bambous & 12 & 9 & 21 & 2 \\
Marie-Galante & Folle Anse & & 1 & 1 & 1 \\
& Grotte Blanchard & 9 & 1 & 10 & 5 \\
& Grotte Blanchard 2 & 1 & & 1 & 1 \\
& Grotte Cadet 2 & 11 & 5 & 16 & 3 \\
& Abri Cadet 3 & 38 & 13 & 51 & 8 \\
La Désirade & Pointe Gros Rempart 6 & & 1 & 1 & 1 \\
Saint Martin & Hope Estate & 1 & & 1 & 1 \\
\hline & Total NISP & 72 & 30 & 102 & 22 \\
\hline
\end{tabular}

Among the A. cunicularia remains, we identified 2 females from Grotte Blanchard and Cadet 2, and a juvenile or subadult from Cadet 2 and Abri Cadet 3 . We also identified a total of 16 unsexed adult specimens from 6 sites and 12 archaeological levels (Table 2).

More than $50 \%$ of the remains are talons and leg bones, primarily tibiotarsus and tarsometatarsus (Supplemental Table S2). This species is also represented by several wing bones and shoulder girdle elements, as well as a limited number of cranial and axial elements. While cranial bones are generally fragmentary, the morphology of 3 beaks and 2 quadrates allow them to be attributed to the Burrowing Owl.

Bones of the shoulder girdle and sternum are infrequent. Distinctive characters of the Athene cunicularia coracoid include a broad, triangular procoracoid process, the shape of the head, and the facies articularis humeralis or glenoid facet (Olson and Hilgartner 1982). These traits are preserved on 4 remains from 3 individuals recovered at 3 sites (Supplemental Fig. S4 and Table S2).

With regard to the wing, 17 elements have been attributed to the Burrowing Owl. A complete humerus from Grotte Blanchard is slightly shorter than our comparative material, but its greatest length is equivalent to larger Antillean A. cunicularia fossils (Supplemental Table S1), while the morphology of the proximal and distal ends fit well with those identified by Olson and Hilgartner for Athene cunicularia (Supplemental Fig. S5). Distal measurements of fragmented humeri from Grotte des Bambous and Grotte Blanchard are also broader than other Caribbean fossil material, suggesting they belong to a subspecies of Athene cunicularia that is larger than those from Florida and Hispaniola (Supplemental Table S1).

The ulna is represented by 4 fragments (Supplemental Table S2); 2 proximal fragments from Grotte des Bambous and Cadet 3 are attributable to the Burrowing Owl based on the apophysis glenoidalis interna (cotyla ventralis or internal cotyla) and a deep, well-defined impressio brachialis (radial depression). 
Table 2. Number of identified specimens (NISP), minimal number of element (MNE) and minimal number of individuals (MNI) of Athene cunicularia and cf. Athene cunicularia ${ }^{a}$ (in brackets) in all levels of the 8 sites.

\begin{tabular}{|c|c|c|c|c|c|c|c|c|}
\hline \multirow[t]{2}{*}{ Epoch } & \multirow[t]{2}{*}{ Period } & \multirow[t]{2}{*}{ Site } & \multirow[t]{2}{*}{ Unit } & \multirow[t]{2}{*}{ NISP } & \multirow[t]{2}{*}{ MNE } & \multirow{2}{*}{$\frac{\mathrm{MNI}}{\text { Female }}$} & $\mathrm{MNI}$ & \multirow{2}{*}{$\frac{\text { MNI }}{\text { Adult/unsexed }}$} \\
\hline & & & & & & & Juvenile/subadult & \\
\hline \multirow[t]{11}{*}{ Holocene } & Preceramic-Colonial & Grotte Cadet 2 & $4^{\prime}$ & $11(+2)$ & 11 & 1 & 1 & 1 \\
\hline & Colonial & Grotte Blanchard 2 & & 1 & 1 & & & 1 \\
\hline & & Abri Cadet 3 & $A$ & $2(+1)$ & 2 & & & 1 \\
\hline & Ceramic & Folle Anse & 1 & (1) & & & & \\
\hline & & Grotte des Bambous & & $12(+9)$ & 12 & & & 2 \\
\hline & & Pointe Gros Rempart 6 & 3 & (1) & & & & \\
\hline & & Abri Cadet 3 & $B-D$ & $18(+7)$ & 16 & & 1 & 3 \\
\hline & & Hope Estate & 5 & 1 & 1 & & & 1 \\
\hline & Preceramic & Abri Cadet 3 & G-I & $10(+2)$ & 10 & & & 1 \\
\hline & & Grotte Blanchard & 1 & $5(+1)$ & 5 & & & 1 \\
\hline & Pre-human & Grotte Blanchard & 2 & 1 & 1 & & & 1 \\
\hline \multirow[t]{5}{*}{ Pleistocene } & & Abri Cadet 3 & $\mathrm{~J}-\mathrm{K}$ & $8(+3)$ & 8 & & & 2 \\
\hline & & Grotte Cadet 2 & $5 a$ & (3) & & & & \\
\hline & & Blanchard & 5 & 2 & 2 & 1 & & 1 \\
\hline & & Blanchard & 6 & 1 & 1 & & & 1 \\
\hline & & & Total & $72(+30)$ & 70 & 2 & 2 & 16 \\
\hline
\end{tabular}

a The abbreviation "cf." (conformis) is used for remains tentatively referred to the Athene cunicularia. 
Three proximal carpometacarpi from Abri Cadet 3 have oblique processus extensorius with a rounded end and a narrow spatium intermetacarpale (Kessler 2017). The damaged processus pisiformis is in line with the mid-shaft of the major metacarpal (Olson and Hilgartner 1982). The facies articularis digitalis minor and the sulcus tendinous of the specimen from Grotte Blanchard are similar to those observed on modern specimens.

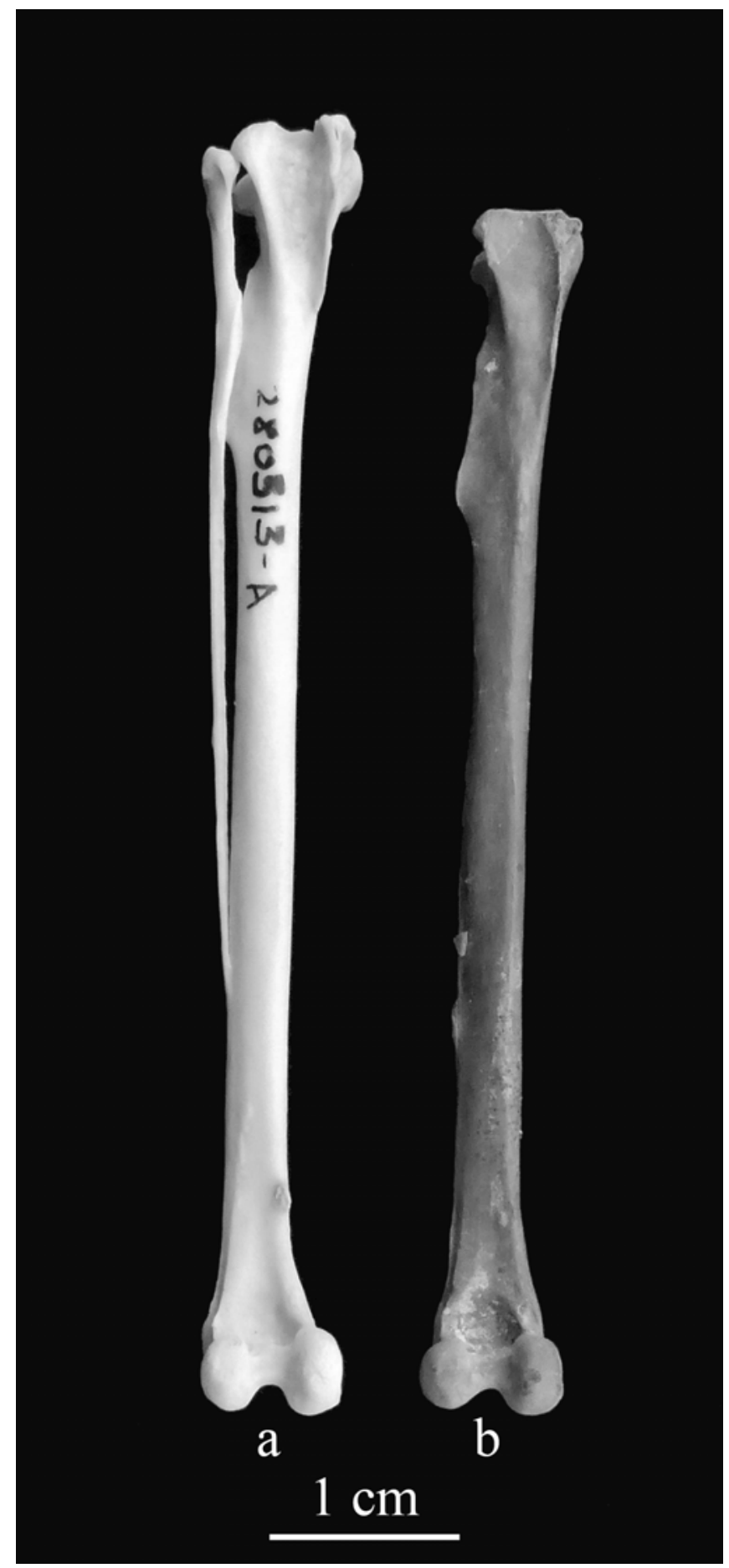

Figure 2. Right tibiotarsi of Athene cunicularia in cranial view: (a) reference collection (MEC 280313-A) and (b) Grotte Cadet 2 (GC2-2018U4).

The first wing phalanx from Grotte Cadet 2, although smaller than modern specimens, shows the same morphological traits observed on Athene. The proximal end is straight and the dorsal side is rounded, as with Athene and Tyto, but the distal end is protuberant unlike Tyto (Kessler 2017). Leg elements are represented by 41 bones. A femur from Grotte des Bambous and one from Grotte Cadet 2 are referred to $A$. cunicularia on the basis of a developed trochanteric ridge. The complete and 
near-complete tibiotarsi from Grotte des Bambous, Grotte Cadet 2, and Cadet 3 present, in their distal portion, nearly parallel condyles, which distinctly undercut the medial side of intercondylar bar, and a wide, deep sulcus extensorius, identical to modern A. cunicularia (Fig. 2). In their proximal portion, these elements and 2 proximal fragments from Grotte Blanchard and Abri Cadet 3 present a welldeveloped crista cnemialis cranialis and the edge of the facies articularis medialis in medial aspect are similar to the one observed in our modern comparative specimens of $A$. cunicularia. Some variations in the size of this bone were noted. The material from Grotte Blanchard includes a robust tibiotarsus from an unsexed individual and a gracile tibiotarsus with medullary bone indicating a female individual, while 3 specimens intermediate in size are present in the bone assemblages from Grotte des Bambous, Cadet 2, and Abri Cadet 3 (Supplemental Table S1).

The anatomical features described by Olson and Hilgartner (1982: p. 40-41) for A. cunicularia tarsometatarsus are present on 2 complete specimens from Grotte des Bambous and Cadet 2: a divided musculus tibialis cranialis attachment (Supplemental Fig. S6), short calcaneal ridge on the hypotarsus (Supplemental Fig. S7), the morphology and orientation of the trochleae (Fig. 3). This latter trait is also found on the tarsometatarsus trochlea of the Hope Estate specimen. In addition, greatest length measurements of a tarsometatarsus from Grotte des Bambous on Grande Terre and a subadult bone from Grotte Cadet 2 on Marie-Galante are consistent with the large A. c. guadeloupensis form (Supplemental Fig. S8 and Table S1). By contrast, the Hope Estate specimen from Saint Martin, even if too fragmentary to be measured, appears to come from a very small Burrowing Owl. Pedal phalanges are numerous ( $\mathrm{n} 1 / 421)$ and represent the 4 digits.
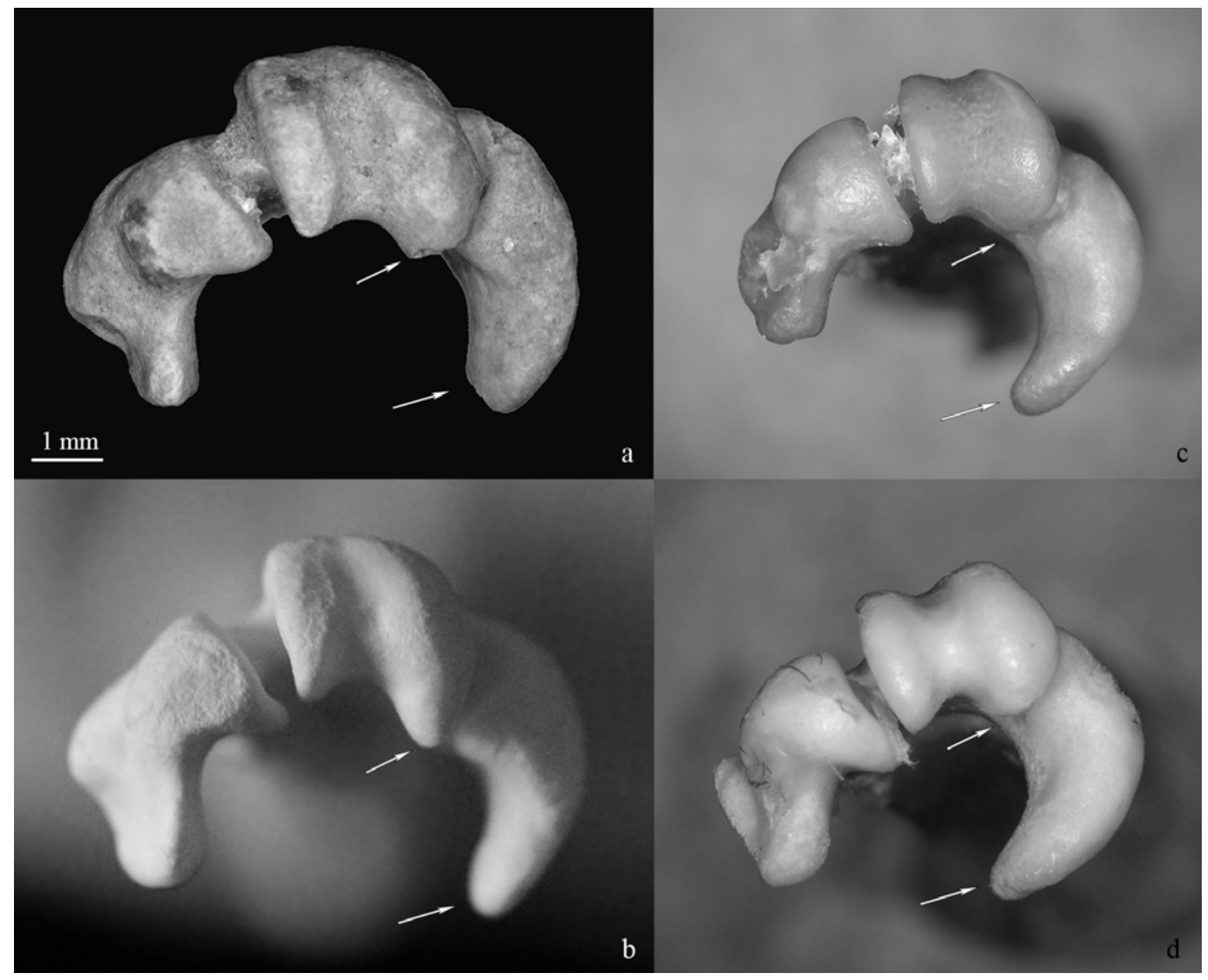

Figure 3. Characters of the distal end of the tarsometatarsus (a) right, (b-d) left: orientation of the trochleae and condyles position (figure 6 in Olson and Hilgartner 1982). (a) Athene cunicularia from Abri Cadet 3 (AC3-2018-05 reverse image) and (b) from reference collection (PACEA-O-758); (c) Megascops nudipes (USNM 501799) and (d) Margarobyas lawrencii (USNM 554287). 


\section{Chronological and geographical distribution}

The Pleistocene and early Holocene Burrowing Owl fossils considered here come from 3 neighboring sites on Marie-Galante (Table 2). It is worth mentioning that Historic Age sites on MarieGalante have also yielded the remains of Burrowing Owls.

On the islands of Saint Martin, Guadeloupe, and La Désirade, the remains confidently or tentatively referred to this species come primarily from Ceramic Age sites, while a radiocarbon date of 1445-1631 CE (385 630 BP, Lyon-14109, SacA-49751) obtained on an A. cunicularia ulna from Grotte des Bambous provides direct evidence for the presence of this owl on Grande Terre during the later stage of the Native American occupation of the islands (i.e., the Contact period).

\section{Discussion}

The past distribution of the Burrowing Owl in the Greater Antilles ranged from Cuba and the Bahamas to Puerto Rico (Fig. 4, Supplemental Table S3). In the Lesser Antilles, fossil remains of this taxon were previously known from 3 islands (Antigua, Barbuda, Sint Eustatius), with several specimens coming from Amerindian sites dated to the Ceramic Age (ca. 500 BCE-1,500 CE). In Antigua, Burrowing Owl bones have been recovered from the Mill Reef Amerindian site (Wing et al. 1968), Burma Quarry (Steadman et al. 1984), and more recently from the Royall's site (Healy et al. 2001), while on St. Eustache, the Burrowing Owl has been identified during excavations at Golden Rock (van der Klift 1992). This latter island, where no historical specimens were collected by naturalists, would nevertheless have recently been home to the owl. This is supported by Ober's account of owls flying at night in the forest bordering the slopes of the island's volcano (Ober 1900: p. 242).
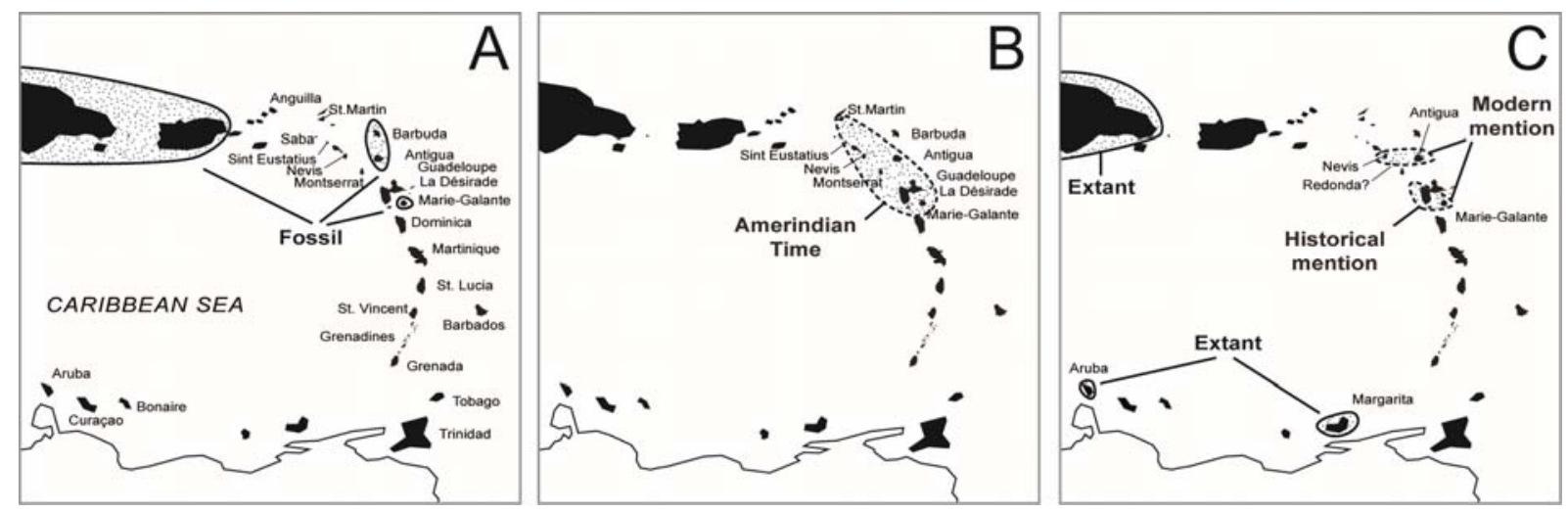

Figure 4. The past (A-B) and recent distributions (C; eBird 2020) in stippled area of Athene cunicularia in the Lesser Antilles. For detailed site information see Supplemental Table S3.

The number of bones attributed to this species at Royall's and Golden Rock is not specified, but it is probably low, since these sites produced only small avifauna assemblages. At Mill Reef, the owl is represented by only one specimen (Wing et al. 1968). The limited number of sites yielding Burrowing Owl and the small number of remains recovered from these sites reinforces the rarity of the species during pre-Columbian periods and is in good agreement with the hypothesis of a population decline as a consequence of the reduction of its habitat.

In contrast, owl bones are found in greater numbers on paleontological sites. The Burma Quarry site in Antigua is an infilled fissure containing material dated to 2,300-500 BCE, and thus contemporaneous with the early human settlement of the Lesser Antilles (Steadman et al. 1984). Sixtyfour Burrowing Owl bones representing at least 13 individuals were recovered from the site (Pregill et al. 1988). The bones are distributed throughout the deposit, with the Burrowing Owl being the most 
common bird species. This predominance of owl remains could reflect the fact that owls lived in the immediate vicinity of the site or that bones were accumulated by other owls (Pregill et al. 1988).

In Barbuda, more than 80 Burrowing Owl bones were collected from 5 caves: caves I to III and V on the cliff above Two Foot Bay, and a cave referred to as "Rat Pocket" (Pregill et al. 1994). While none of these sites have been radiometrically dated, Pregill and colleagues consider the deposits to be primarily Pleistocene (Pregill et al. 1994: p. 16). The Burrowing Owl is once again the most represented bird species in the first 4 sites. The fact that more Burrowing Owl bones on both Barbuda and Antigua have been recovered from natural sites, particularly very old sites, than any other extirpated bird species, while at the same time being relatively rare in Amerindian archaeological sites, is consistent with the interpretation of an ancient population reduction. It could also reflect various taphonomical accumulation processes between older and younger sites, the latter particularly affected by human activity.

In this context, our data raise several points of discussion. Firstly, our results provide the first clear evidence for the presence of the Burrowing Owl in Marie-Galante's fossil record. Although previously suspected based on a small number of strigiform bones from the pre-Columbian Ceramic Age site of Tourlourous (Colas et al. 2002, Grouard 2016), as well as a phalanx from Abri Cadet 3 cautiously assigned to this taxon (cf. Athene cunicularia in Sierpe 2011 and Stouvenot et al. 2014), we identified more than $70 \mathrm{owl}$ bones from Marie-Galante, 59 of them confidently assigned to the Burrowing Owl. This species is found in all fossil-bearing caves and rock shelters and in a few Amerindian village sites on this island, such as Folle Anse and Tourlourous. The predominance of owl remains in caves and rock shelters is similar to what has been documented for Antigua and Barbuda, and may reflect a preference of Burrowing Owls for these contexts. This is in agreement with museum specimens from Antigua described as having been "dug out of a cliff" by indigenous populations (Lawrence 1878b). Unlike the fossil specimens of this bird from Antigua and Barbuda, the Marie-Galante specimens are primarily Holocene in age, with only 4 bones from layers 5 and 6 of the Grotte Blanchard reliably dating to the Pleistocene, to which can be added 8 uncertain specimens from layer J-K of the Abri Cadet 3 (Table 2, Fig. 4, Supplemental Table S3). This is all the more remarkable given that Marie-Galante's Pleistocene record is well documented at Blanchard, Cadet 2, and Cadet 3. Thus, the Marie-Galante fossil record does not support the hypothesis of a greater abundance of Burrowing Owls during the Pleistocene. In addition, stable isotope measurements obtained on guano from Grotte Blanchard confirmed more arid local Pleistocene environmental conditions that included significant fluctuations (Royer et al. 2017). The second part of marine isotope stage 2 also witnessed a particular arid episode (Royer et al. 2017). The emergence of arid conditions would favor more open environments, which should have been more suitable for the Burrowing Owl. While the Pleistocene layers 5 and 6 of Grotte Blanchard and layer 5a of Grotte Cadet 2 did produce several Burrowing Owl bones, they are much less numerous compared to Holocene horizons at both sites. The frequency of Burrowing Owl remains in fossil sites on MarieGalante therefore appears unconnected to any specific environmental conditions.

Secondly, our data equally provide evidence for a wider Holocene distribution of the Burrowing Owl prior to European colonization. For example, a tarsometatarsus from the Hope Estate site provides the first evidence of this species on the island of Saint Martin. Similarly, the identification of Burrowing Owl remains from Grotte des Bambous attests to its presence on Grande Terre, which contradicts both Bond (1936) and Danforth's (1939) reports, but is consistent with the historical accounts of Breton and Du Tertre. In addition, a small strigid bone from PGR6 suggests that the Burrowing Owl was also present on La Désirade island. These 3 specimens are recent, found from Ceramic Age contexts on Saint Martin and La Désirade and Amerindian to historical context at the Grotte des Bambous. The direct radiocarbon age obtained from the latter site places this taxon to the end of the 15th to the beginning of the 17th century, demonstrating that the Burrowing Owl was still present in Guadeloupe throughout the Contact period and possibly during the first decades of European colonization, as equally suggested by Du Tertre's account. Thus, data from Bambous, Du Tertre's descriptions, and the fact that Ober was unable to obtain specimens during his stay places the extirpation of this taxon from the main Guadeloupe islands (Basse Terre and Grande Terre) sometime between the middle of the 17 th century and the middle of the 19th century. 
Evidence supporting the early historical disappearance of this bird raises questions about the causes underlying it, in particular the hypothesis advanced by Pregill and Olson (1981), according to which the owl is historically recorded only on few islands (Nevis, Antigua, Marie-Galante) as a result of a range contraction coincident with the Pleistocene-Holocene transition and the emergence of unfavorable climate conditions. Caves on Marie-Galante have produced Pleistocene and several Holocene specimens, demonstrating that this owl could cope with mesic Holocene conditions that replaced late Pleistocene arid conditions. Data from Golden Rock on Sint Eustatius, as well as new evidence from Saint Martin, Guadeloupe, and La Désirade, depict a wider geographic distribution for this owl in the Lesser Antilles. When added to the fact that Burrowing Owl remains have been identified from Amerindian and Historic Age sites on these islands, there appears ample evidence for a larger geographical and chronological distribution than considered previously by Pregill and Olson (1981).

Environmental changes since the late Glacial period do not, therefore, account alone for the relict distribution documented in the 20th century. Based on data from the islands of Guadeloupe, where this owl was consistently present, it is only during the first 2-3 centuries of the Colonial period that its numbers dwindle and this taxon disappears. Its extirpation also predates the introduction of the mongoose, indicating that the emphasis placed by early 20th century ornithologists on the presence of this carnivore may have exaggerated its impact. The first 2 centuries of the European colonization also witness a substantial transformation of the Caribbean environment, particularly the decimation of dry forest habitats in lowland areas, which saw most of the historical occupation of the island (Lasserre 1961, Lugo et al. 1981, Watts 1990). The Burrowing Owl is known to be highly sensitive to disturbances (Wiley 1986), making it likely that alterations in its habitats due to the growth of the island's human population directly or indirectly affected this species. For example, nocturnal raptors were historically slaughtered in the Caribbean as they were reputed to bring bad luck (Barbour 1930), while European carnivores introduced to the islands early in the historical period also preyed heavily on these birds (Poulin et al. 2011). Habitat degradation linked to the increasing human settlement of the island during historical periods therefore appears the most parsimonious explanation for the regional extinction of this species.

\section{Acknowledgments}

This study was funded by the ECSIT Project "Ecosystèmes insulaires tropicaux, réponse de la faune indigène terrestre de Guadeloupe 'a 6000 ans d'anthropisation du milieu," conducted by the CNRS with financial support from the European PO-FEDER program (grant $n^{\circ}$ 2016-FED-503), the Guadeloupe Regional Council, the DAC of Guadeloupe (PCR Extinctions), and the CNRS (SEEG ECSIT). We are indebted to the Edgar Clerc Museum of Guadeloupe staff (S. Guimaraes and J-L. Bernos) and Guadeloupe archaeological office staff (G. Robert) who facilitated the access to archaeological collections. We are extremely grateful to $C$. Lefèvre, C. Milensky, and M. Florence who facilitated the loan and consultation of comparative specimens. We thank E. Pubert and N. Antunes for their technical support; N. Jeantet and V. Conche for the 3D modeling; and excavation team members for collecting the material used in this work. We specially thank D. Johnson for his very enthusiastic exchanges and careful editing of a previous version. Finally, we would like to thank the editor, D. Steadman, and one anonymous reviewer for their constructive comments and suggestions.

\section{Literature cited}

Arredondo O. 1976. The great predatory birds of the Pleistocene of Cuba. In: Olson SL, editor. Collected papers in avian paleontology honoring the $90^{\text {th }}$ birthday of Alexander Wetmore. Washington (DC): Smithsonian Institution Press; p. 169-187. 
Arredondo O. 1982. Los Strigiformes f'osiles del pleistoceno cubano [Fossil Strigiformes of the Cuban Pleistocene]. Bolet'ın de la Sociedad Venezolana de Ciencias Naturales. 140:33-55. Spanish. Arredondo O, Olson SL. 1994. A new species of owl of the genus Bubo from the Pleistocene of Cuba. Proceedings of the Biological Society of Washington. 107:436-444.

Barbour T. 1930. Some faunistic changes in the Lesser Antilles. In: Proceedings of the New England Zoological Club. 11:73-85.

Barrow M. 2000. A passion for birds: American ornithology after Audubon. Princeton (NJ): Princeton University Press.

Baumel JJ, Witmer LM. 1993. Osteologia. In: Baumel JJ, King AS, Breazile JE, Evans HE, Vanden Berge JC, editors. Handbook of avian anatomy: Nomina Anatomica Avium. 2nd edition. Cambridge (MA): Publications of the Nuttall Ornithological Club. 23:45-132.

Bond J. 1936. Birds of the West Indies. Baltimore (MD): Academy of Natural Sciences of Philadelphia. Bond J. 1945. Check-list of birds of the West Indies. $2^{\text {nd }}$ edition. Philadelphia (PA): Academy of Natural Sciences of Philadelphia.

Bond J. 1971. Birds of the West Indies. 2nd edition. Boston (MA): Houghton-Mifflin.

Breton R. 1665. Dictionnaire caraïbe-français [Caribbean-French dictionary]. Paris: IRD - Karthala. French.

Breton R. 1978. Relations de I’^le de la Guadeloupe [Reports from the island of Guadeloupe]. BasseTerre: Société d'Histoire de la Guadeloupe (Bibliothèque d'histoire antillaise). French.

Brodkorb P. 1969. An extinct Pleistocene owl from Cuba. Quarterly Journal of the Florida Academy of Sciences. 31:112-114.

Colas C, Bertran P, Chancerel G, Richard G. 2002. Marie-Galante Le Tourlourous (97108005AH). Service Régional de l'Archéologie, Direction régionale des affaires culturelles de Guadeloupe. French.

Cooke SB, D'avalos LM, Mychajliw AM, Turvey ST, Upham NS. 2017. Anthropogenic extinction dominates Holocene declines of West Indian mammals. Annual Review of Ecology, Evolution, and Systematics. 48:301-327.

Cory CB. 1886. The birds of the West Indies, including the Bahama Islands, the Greater and the Lesser Antilles, excepting the Islands of Tobago and Trinidad. Auk. 3:454-472.

Danforth ST. 1939. Birds of Guadeloupe and adjacent islands. Puerto Rico University Journal of Agriculture. 23:9-46.

Deignan HG. 1961. Type specimens of birds in the United States National Museum. Washington (DC): United States Government Printing Office. Smithsonian Institution Bulletin Number 221.

de Lasfrenaye F. 1843. Sur un petit groupe d'oiseaux des Antilles [On a small group of birds from the West Indies]. Revue zoologique. 6: 66-68. French.

de Lafresnaye F. 1844. Description de quelques oiseaux de la Guadeloupe [Description of some birds of Guadeloupe]. Revue zoologique. 7: 167-169. French.

Du Tertre J-B. 1667. Histoire générale des Antilles habitées par les Français [General history of the West Indies inhabited by the French]. Paris: Thomas Iolly. French.

eBird. 2020. eBird: An online database of bird distribution and abundance. Ithaca (NY): Cornell Lab of Ornithology [cited 18 Sep 2020]. www.ebird.org

Fitzpatrick SM. 2015. The Pre-Columbian Caribbean: Colonization, population dispersal, and island adaptations. PaleoAmerica. 1:305-331.

Gill F, Donsker D. 2019. IOC world bird list. Version 9.2 [cited Oct 2019]. https://www.worldbirdnames.org/bow/owls/

Greenway JC. 1967. Extinct and vanishing birds of the world. 2nd edition. New York (NY): Dover Publications.

Grouard S. 2016. Les ensembles de faune vertébrée des occupations cedrosan-saladoïdes et troumassantroumassoïdes [The groups of vertebrate fauna of the cedrosan-saladoid and troumassan-troumassoid occupations]. In: Capesterre-de-Marie-Galante. Stade José Bade: Les occupations cedrosan-saladoïde et troumassan-troumassoïde de Tourlourous. Bègles: Inrap GSO; p. 287-318. French. 
Healy PF, Murphy AG, Cruz DM. 2001. Excavations at the Royall's site (JO 11) Antigua, an inland saladoïd settlement. St George, Grenada: IAcA; p. 216-232.

Hofman CL, Hoogland ML, Delpuech A. 1999. New perspectives on a Huecan Saladoid assemblage on Guadeloupe: The case of Morel I. Archaeological investigations on St Martin (Lesser Antilles). The sites of Norman Estate, Anse des P'eres, and Hope Estate. With a contribution to the 'La Hueca problem.' Archaeological Studies Leiden University. 4:303-312.

Horst GR, Hoagland DB, Kilpatrick CW. 2001. The mongoose in the West Indies: The biogeography and population biology of an introduced species. Biogeography of the West Indies: Patterns and Perspectives. 2:409-424.

Hume JP. 2017. Extinct birds. 2nd edition. London (UK): Bloomsbury Natural History.

Hume JP, Walters M. 2012. Extinct birds. London (UK): T \& AD Poyser.

Jenkins CN, Pimm SL, Joppa LN. 2013. Global patterns of terrestrial vertebrate diversity and conservation. PNAS. 110: E2602-E2610.

Keegan WF, Hofman CL, Ramos RR. 2013. The Oxford handbook of Caribbean archaeology. New York (NY): Oxford University Press.

Keegan W, Hofman CL. 2017. The Caribbean before Columbus. New York (NY): Oxford University Press.

Kessler JE. 2017. Evolution and skeletal characteristics of European owls. Ornis Hungarica. 25:65-103.

König C, Weick F. 2008. Owls of the world. 2nd edition. London (UK): Christopher Helm Publishers.

Lasserre G. 1961. La Guadeloupe, étude géographique [Guadeloupe, geographical study]. Bordeaux: Union française d'impression. French.

Lawrence GN. 1878a. Catalogue of the birds of Antigua and Barbuda, from collection made for the Smithsonian Institution, by Mr Fred A. Ober, with his observations. Proceedings of US National Museum. 1:232-242.

Lawrence GN. 1878b. Catalogue of the birds of Dominica from collections made for the Smithsonian Institution by Frederick A. Ober, together with its notes and observations. Proceedings of the US National Museum. 1:48-69.

Lugo AE, Schmidt R, Brown S. 1981. Tropical forests in the Caribbean. Ambio. 10:318-324.

Marks JS, Cannings RJ, Mikkola H. 1999. Family Strigidae (typical owls). In: del Hoyo J, Elliott A, Sargatal J, editors. Handbook of the birds of the world. Volume 5.

Barn-owls to hummingbirds. Barcelona (Spain): Lynx Edicions; p. 76-242.

Morgan GS. 1994. Late Quaternary fossil vertebrates from the Cayman Islands. In: Brunt MA, Davies $\mathrm{JE}$, editors. The Cayman Islands: Natural history and biogeography. Dordrecht: Springer Netherlands (Monographiae Biologicae); p. 465-508.

Noble GK. 1916. The resident birds of Guadeloupe. Bulletin of the Museum of Comparative Zoology at Harvard College. 60:359-375.

Ober F. 1900. The storied West Indies. New York (NY): D. Appleton and Company.

Olson SL. 1978. A paleontological perspective of West Indian birds and mammals. In: Zoogeography of the Caribbean. Academy of Natural Sciences of Philadelphia, Special Publication 13; p. 99-117.

Olson SL, Hilgartner WB. 1982. Fossil vertebrates from the Bahamas. Smithsonian Contributions to Paleobiology. 48:25-55.

Olson SL, Steadman DW. 1977. A new genus of flightless ibis (Threskiornithidae) and other fossil birds from cave deposits in Jamaica. Proceedings of the Biological Society of Washington. 90:447-457.

Poulin RG, Todd LD, Haug EA, Millsap BA, Martell MS. 2011. Burrowing Owl (Athene cunicularia). In: Poole A, editor. Birds of North America. Ithaca (NY): Cornell Lab of Ornithology. http://bna.birds.cornell.edu./bna/species/061

Pregill GK, Olson SL. 1981. Zoogeography of West Indian vertebrates in relation to Pleistocene climatic cycles. Annual Review of Ecology and Systematics. 12:75-98.

Pregill GK, Steadman DW, Olson SL, Grady FV. 1988. Late Holocene fossil vertebrates from Burma Quarry, Antigua, Lesser Antilles. Smithsonian Contributions to Zoology. 463:1-27. 
Pregill GK, Steadman DW, Watters DR. 1994. Late Quaternary vertebrate faunas of the Lesser Antilles: Historical components of Caribbean biogeography. Bulletin of the Carnegie Museum of Natural History. 30:1-51.

Raffaele HA, Wiley J, Garrido OH, Keith A, Raffaele JI. 2003. Birds of the West Indies. Princeton (NJ): Princeton University Press.

Rangel-Salazar JL, Enr'ıquez PL. 2017. Introduction: The birds in the Neotropical region. In: Enriquez $\mathrm{PL}$, editor. Neotropical owls: Diversity and conservation. Cham (Switzerland): Springer International Publishing; p. 1-6.

Ridgway R. 1914. Birds of North and Middle America. US National Museum Bulletin. 50:594-825.

Royer A, Malaizé B, Lécuyer C, Queffelec A, Charlier K, et al. 2017. A high-resolution temporal record of environmental changes in the Eastern Caribbean (Guadeloupe) from 40 to $10 \mathrm{ka}$ BP. Quaternary Science Reviews. 155:198-212.

Sierpe V. 2011. Analyses, détermination et évaluation du complexe archéozoologique insulaire de I'abri Cadet 3, Marie-Galante, Archipel de la Guadeloupe [Analyses, determination and evaluation of the island archaeozoological complex of the Cadet Shelter 3, Marie-Galante, Archipelago of Guadeloupe] [master's thesis]. Paris (France): Muséum National d'Histoire Naturelle. French.

Steadman DW, Hilgartner WB. 1999. A new species of extinct barn owl (Aves: Tyto) from Barbuda, Lesser Antilles. Smithsonian Contributions to Paleobiology. 89:75-83.

Steadman DW, Pregill GK, Olson SL. 1984. Fossil vertebrates from Antigua, Lesser Antilles: Evidence for late Holocene human-caused extinctions in the West Indies. Proceedings of the National Academy of Sciences. 81:4448-4451.

Stouvenot C, Grouard S, Bailon S, Bonnissent D, Lenoble A, et al. 2014. L'abri sous roche Cadet 3 (Marie-Galante): un gisement à accumulations de faune et à vestiges archéologiques [The rock shelter Cadet 3 (Marie-Galante): a deposit with accumulations of fauna and archaeological remains]. In: Bérard B, editor. Actes du 24e Congrès de I'AIAC. Fort-de-France, Martinique; $p$. 126-140. French.

Suárez W, Olson SL. 2015. Systematics and distribution of the giant fossil barn owls of the West Indies (Aves: Strigiformes: Tytonidae). Zootaxa. 4020:533-553.

van der Klift HM. 1992. Faunal remains of the Golden Rock site. In: Versteeg AH, Schinkel K, editors. The archaeology of St. Eustatius, the Golden Rock site. Publication of the Foundation for Scientific Research in the Caribbean Region; p. 74-84.

von den Driesch A. 1976. A guide to the measurements of animal bones from archaeological sites. Peabody Museum Bulletin.

Watts D. 1990. The West Indies: Patterns of development, culture and environmental change since 1492. New York (NY): Cambridge University Press.

Weick F. 2006. Owls (Strigiformes): Annotated and illustrated checklist. Berlin: Springer-Verlag Berlin Heidelberg.

Weick F. 2018. Der Kaninchenkauz Athene cunicularia (Molina) 1782. Bemerkungen zu Biologie, Verbreitung, den Rassen und zur Systematik [The Burrowing Owl Athene cunicularia (Molina) 1782. Remarks on biology, distribution, races and systematics]. Ökol. Vögel. 33:91-123. German.

Wetmore A. 1937. Bird remains from cave deposits on Great Exuma Island in the Bahamas. Bulletin of the Museum of Comparative Zoology. 80:427-441.

Wiley JW. 1986. Status and conservation of raptors in the West Indies. Birds of Prey Bulletin. 3:5770.

Wing ES, Hoffman CA, Ray CE. 1968. Vertebrate remains from Indian Sites on Antigua, West Indies. Caribbean Journal of Science. 8:123-139. 